\title{
How molecular biology won its place in the USSR
}

Professor Tumerman was originally a physicist. He later turned his attention to molecular biology-a change which, he explained, reflected the whole story of his life in Russia.

Owing to the stress placed by Soviet defence policy of the early 1950s on the atomic bomb, physicists enjoyed what was, for those days, a relatively privileged position. They had greater freedom of action than other scientists and according to Tumerman, played a leading role in the fight against Lysenko.

In the early 1950s a number of physicists became interested in molecular biology and started working underground. Frequently, said Tumerman, the physicists acted as hosts to such unauthorised gatherings. "Timofeev-Resovskii's first lecture on genetics was given in Kapitsa's Institute of Physical Problems", he said. "I myself organised the first seminar on genetics at the Lebedev Physical Institute. We had about 200-300 participants at every meeting of the seminar. This was the first legal seminar on genetics. The time was ripe to begin the fight".

Many famous physicists, including Kurchatov and Tamm, were by now interested in molecular biology, and the pressure was kept up in many forms. An underground seminar was held every year in the Ilmensk nature reserve.

By this time, Professor Tumerman's interests had switched almost completely to molecular biology, although this change was not reflected in his official work. "Before my arrest", he explained casually, referring to his seven years in solitary confinement, "I had worked for 20 years with Sergei Vavilov, as a pure physicist. (Sergei was the brother of Nikolai Vavilov, you remember, who perished during the Lysenko period). We worked together from 1926 to 1947 on fluorescence as a physical phenomenon. The first fluorescent lamps in Russia were made by my hands."

\section{Genetics-learnt in gaol}

"In the Vladimir prison, there was a very good library-built up from books confiscated from the homes of prisoners. I began to read books on genetics. There was one very good book by Sunnot and Dent. These books impressed me so much that after I was released I changed my field of interest. I felt that purely physical phenomena were no longer of interest to me. I could only work at the interface of physics and molecular biology. I wanted to understand the role of physics in biological processes. So from 1954 to
PROFESSOR Lev Tumerman, who played a leading role in the fight against Lysenkoism, emigrated from the Soviet Union to Israel in 1972. Since then, he has been prominent in the press discussion of the Kyshtym nuclear "disaster" of the 1950s. Vera Rich talked to him recently at the Weizmann Institute, where he now teaches.

1958, I worked at the Lebedev Physical Institute, but I changed my field of activity to photosynthesis. This was my official work, but unofficially was interested in the whole problem of genetics and molecular biology."

In the seminars which Tumerman and his fellows organised, little could be done except to present and review the results of foreign papers. Yet, although no experimental work could be done at that time in molecular biology, Tumerman sees the seminars as far from fruitless. "We felt it was very important to involve young people in this field - to give an impetus to press the authorities. And in 1958 we won our victory, and molecular biology was allowed to exist officially."

As an immediate consequence of the new policy, Academician Engelhardt was given the task of setting up a new Institute of Molecular Biology, and Tumerman himself was invited to be head of the Laboratory of Bioenergetics. This laboratory investigated a number of problems, including nucleic acids and photosynthesis; Tumerman's own work was an attempt to apply physical mechanisms to problems of molecular biology.

"During the last few years", Tumerman added, "genetic engineering has evolved. But this came up after I had emigrated and I know nothing about it. I never worked on military applications. It was not easy for me-they often pressed me, but I managed to stay clear of military problems."

Yet although his own work remained unclassified, Tumerman did in fact come into possession of certain data which, whether technically classified or not, the Soviet authorities clearly wanted to keep secret. This was the story of the Kyshtym disaster.

"In the early 1960s", explained Tumerman, "Timofeev-Resovskii was working at the Inmensk nature reserve on the action of radiation on plants, and there was certainly no contamination there". (This is the nature reserve where the clandestine meetings on molecular biology and genetics had been held.)

At that time, Tumerman's brother was working as a construction engineer on the new atomic power station at Beloyarsk, some $100 \mathrm{~km}$ away. One day, Tumerman set out to visit his brother by car, leaving at midnight. "By 5.30 it was light", he recalled, "and I saw a sign by the road "No stopping for $25-30 \mathrm{~km}$ '.

"On both sides there was mertvaya zemlya (dead land). No villages, only chimneys - the houses had been pulled down to keep the people from returning".

Asked to clarify the expression mertvaya zemlya, Tumerman explained that by 'dead land' he did not mean there was any signs of devastation. The land was simply empty-no agriculture or any other sign of land-use. "The local people said it was due to a "catastrophe' at Kyshtym", he said. "I don't have any knowledge of its cause or nature. It had been some years before. I assumed that some waste must have fallen and that the level was so high that the people had had to be evacuated and many hundreds of square kilometres of land left free from cultivation".

\section{Keeping quiet about Kyshtym}

Tumerman at first made no attempt to publicise this knowledge. Only when, some years after Tumerman settled in Israel, Zhores Medvedev began to draw Western public attention to the disaster, did Tumerman begin cautiously to publish what he knew.

"I was afraid," he explained, "that people would use the story to interfere with the building of atomic power stations. I believe that the building of atomic power stations-real power stations, not plutonium processing plants-is the prime necessity for mankind. We must be prepared that in maybe 20 years the oil will run out. And world politics will change. No one will be interested in the Middle East"

"I published my account", he insisted, "to prove that the danger is not in atomic power stations. Atomic power stations are the safest form of energy production, much safer than oil".

However one accepts this estimate, Professor Tumerman's assertion that Kyshtym was not due to some power station disaster seems, on the face of it, irrefutable. For at the time when he passed through the devastated area, he was on his way to visit his brother at Beloyarsk, where the first atomic power station in the Soviet Union was "only at the first stage of building". "So whatever caused the disaster", Tumerman concluded, "it simply could not have been connected with any power station!" 